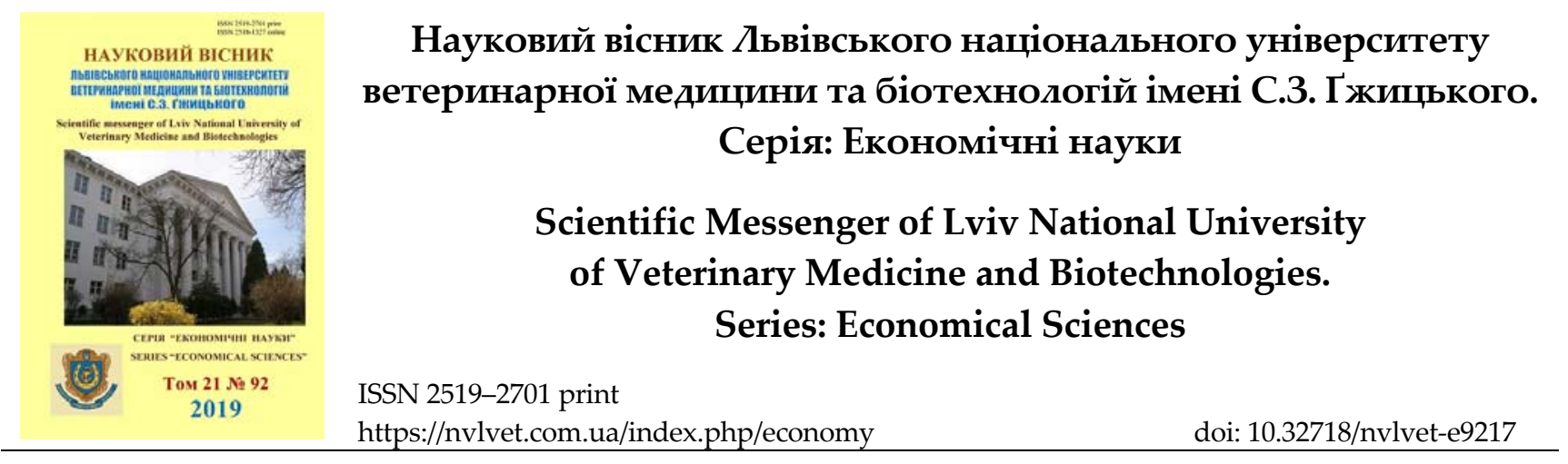

UDC 339.138

\title{
Digital marketing instrument in the conditions of development of the informational economy
}

\author{
M. Dorosh-Kizym, O. Dadak, T. Gachek \\ Stepan Gzhytskyi National University of Veterinary Medicine and Biotechnologies Lviv, Ukraine
}

Article info

Received 04.02.2019

Received in revised form 05.03 .2019

Accepted 06.03.2019

Stepan Gzhytskyi National University of Veterinary Medicine and Biotechnologies Lviv,

Pekarska Str., 50, Lviv,

79010, Ukraine.

Tel.: +38-063-814-56-55

E-mail:mim.dorosh@gmail.com

Dorosh-Kizym, M., Dadak, O., \& Gachek, T. (2019). Digital marketing instrument in the conditions of development of the informational economy. Scientific Messenger of Lviv National University of Veterinary Medicine and Biotechnologies. Series: Economical Sciences, 21(92), 104-109. doi: $10.32718 /$ nvlvet-e9217

The evolution of marketing, large volumes of data, analytics and the enormous growth of advertising in the consumer information space, have led to a global transformation of marketing functions. Today, marketing, retaining its functional tools, is changing and modifying. Marketing systems primarily focus on understanding the process of shaping consumer decisions. Given that people spend most of their time in the digital world, marketers should work in it as effectively. It is difficult to imagine the successful operation of any enterprise without a well-established marketing activity. In a modern economy, the question of the role of marketing in the enterprise is acute. Manufacturers, trying to sell their goods intensively use all marketing tools, in particular - advertising. Aggravating competition in most markets requires the formation of mobile marketing systems of the enterprise. The basis of modern society is the rapidly growing network of electronic knowledge and tools that covers manufacturers, suppliers, sellers, buyers and users of information in electronic form. The experience of recent years shows that traditional unified marketing techniques no longer work with the expected effect, so new creative ways to promote a product or service to the market should be introduced into the marketing system in order to meet the needs of an overly demanding consumer. Each year, technology is moving forward, new trends are gaining momentum, affecting all the schemes that people make business in the digital world. And in order to be ahead of competitors, or even simply to "stay in the game", you need to learn how to work with new tools, track trends and be flexible enough to adapt to these changes.

Key words: marketing tools, marketing mix, interactive marketing, digital marketing, ambient media, crazy PR, storytelling, inbound marketing, tryvertising, sensitive marketing, identity marketing, shockvertising.

\section{Інструментарій цифрового маркетингу в умовах розвитку інформаційної економіки}

\author{
М.М. Дорош-Кізим, О.О. Дадак, Т.С. Гачек
}

Львівський національний університет ветеринарної медицини та біотехнологій імені С.3. Гжицького, м. Львів, Украӥна

Еволючія маркетингу, великі обсяги даних, аналітика та колосальне зростання реклами в інформаційному просторі споживача, зумовили глобальну трансформацію маркетингових функцій. Сьогодні маркетинг, зберігаючи свої функиіональні інструменти, змінюється та модифікується. Маркетингові системи першочергово орієнтуються на розуміння процесу формування рішень споживачів. Зважаючи на те, шзо люди проводять більшість свого часу в иифровому світі, - маркетологи мають працювати в ньому настільки ж ефективно. Важко уявити успішне функціонування будь-якого підприємства без добре налагодженої маркетингової діяльності. У умовах сучасної економіки гостро постає питання ролі маркетингу на підприємстві. Виробники, намагаючись продати свій товар інтенсивно використовують весь інструментарій маркетингу, зокрема, - рекламу. Загострення конкурениії на більшості ринків вимагає формування мобільних систем маркетингу підприємства. Основу сучасного суспільства складає 
стрімко зростаюча мережа електронних знань та інструментів, щзо охоплює виробників, постачальників, продавців, покупиів $i$ користувачів інформацї в електронній формі. Досвід останніх років показує, що традиційні уніфіковані прийоми маркетингу вже не спрацьовують з очікуваним ефектом, тому в систему маркетингової діяльності слід впроваджувати нові креативні способи просування продукту чи послуги на ринок, щуоб задовольнити потреби надмірно вибагливого сучасного споживача. Щороку технологї йдуть вперед, набирають обертів нові тенденції, шзо впливають на всі схеми, за якими люди роблять бізнес у ичифровому світі. І для того, щуоб бути попереду конкурентів, або навіть просто для того, щзоб “залишатися в грі”, необхідно вчитися працювати з новими інструментами, відстежувати тренди та бути достатньо гнучким, щуоб адаптуватися під ці зміни.

Ключові слова: маркетингові інструменти, маркетинг-мікс, інтерактивний маркетинг, digital-маркетинг атьіепt теdia, сrаzу $P R$, storytelling, inbound marketing, tryvertising, sensitive marketing, identity marketing, shockvertising.

\section{Вступ}

Інформація це важлива рушійна сила економічного зростання та соціальних змін. Бурхливий розвиток інформаційних технологій призвів до того, що в сучасній світовій економіці інформація стала ключовим поняттям. Успішний розвиток мережі Інтернет та бурхливе зростання електронної комерції в черговий раз довели, що інформаційний сектор економіки, на даний момент $є$ найбільш динамічним та найбільш прибутковим.

Глобальні тенденції до швидкісного обміну інформацією сприяють збільшенню обсягів міжнародної електронної комерції. У сучасному динамічному маркетинговому середовищі важливо досліджувати особливості поведінки споживача, виявляючи його віртуальні інформаційні звички, при користуванні e-shop. Вплив глобалізації на зміну вимог до формування конкурентних переваг високотехнологічних підприємств привертає особливу увагу до запровадження сучасних релевантних інструментів інтерактивного маркетингу.

В умовах перенасичення інформаційного простору споживач стомився від стандартних рекламних повідомлень, схожих один на одного, які часто викликають роздратування. Неефективними бувають і занадто креативні пропозиції, за якими не видно вже самого продукту. Таким чином, все частіше має місце ситуація, коли ні мільйонні бюджети, ні незвичайні рекламоносії вже не в змозі пробити дорогу до свідомості інформаційно-стомленого споживача.

Аналіз останніх досліджень і публікаиій. Актуальність даного дослідження знаходить своє відображення у численних наукових працях українських i зарубіжних вчених. Теоретичні принципи та практичні аспекти застосування маркетинг-міксу були розглянуті в роботах С. Гаркавенко, Л. Федулової, Н. Бутенко, Г. Азоєва, А. Старостіної, Т. Примак, Н. Бордена, Д. Каллітона, тощо.

Формулювання ичілей статті полягає в дослідженні доречності впровадження та застосування інноваційних інструментів digital маркетингу, висвітлення їх переваг та недоліків у порівнянні з традиційним класичним набором комплексу маркетингу.

\section{Результати та їх обговорення}

У час цифрових комунікацій в глобальному просторі ринкова ситуація настільки стрімко змінюється, що важко не погодитись, що ще $з$ десяток років тому про такий напрям як digital-маркетинг у нашій державі майже ніхто нічого не чув, і навіть більше того, - деякі підприємці й досі віддають перевагу оголошенням у газетах та журналах, а не контекстній рекламі.

Digital-маркетинг (цифровий маркетинг) - загальний термін, який використовують для позначення інтерактивного маркетингу товарів і послуг, що використовує цифрові технології для залучення потенційних клієнтів і утримання їх як споживачів. Головними завданнями цифрового маркетингу є просування бренду і збільшення збуту за допомогою різних методик. Цифровий маркетинг включає в себе великий вибір маркетингових тактик $з$ просування товарів, послуг i брендів. Крім мобільних технологій, традиційних телебачення і радіо методи цифрового маркетингу використовують мережу Інтернет як основний комунікаційний посередник. Digital-маркетинг сьогодні являє собою впливову сферу, і немає іншого такого тренду, який би впливав на світ бізнесу так швидко і потужно, як цифрові технології. Як і будь-який інший вид маркетингу, цифровий маркетинг допомагає досягати максимального результату оптимальним способом, тобто дає змогу економити гроші, уникати зайвих неефективних витрат.

Правильне використання цифрових інструментів маркетингу дозволяє здійснювати комплексне просування бренда компанії та ï продуктів і послуг в цифровому середовищі, включаючи споживачів, а також офлайн споживачів.

Лише незначний відсоток підприємців знає про нові революційні інструменти маркетингу, - і зовсім мало хто наважується першим їх спробувати. I даремно, адже володіти інформацією і втілювати іiі в дії ось що найважливіше. Головна мета будь якого виробника - отримати конкретний результат, а саме прибуток. В сучасну еру інноваційних технологій та процвітання електронної комерції для зростання та зльоту потрібно навчитися застосовувати нові інструменти маркетингу та повністю перезавантажити свій бізнес.

Суб'єктам ринку задля виживання необхідно навчитись адаптовувати свої бізнес-процеси під мінливі умови середовища. Найбільших успіхів досягне той, хто правильно спрогнозує напрям вектора економіки і буде застосовувати адекватні та випереджальні технології маркетингу.

Комплекс маркетингу - це сукупність маркетингових інструментів і методів, що використовуються підприємством для досягнення його ринкових цілей. У комплекс маркетингу входять усі заходи, які запроваджує підприємство для створення й активізації попиту на свій товар. Головна мета розробки такого комплексу - забезпечення стійких конкурентних пе- 
реваг підприємства та завоювання міцних ринкових позицій.

Історично, першим виник термін "маркетинг-мікс" (від англійського слова "mix", що означає "змішувати”), запропонований 1953 року Нілом Борденом, президентом Американської асоціації маркетингу, на одному із засідань цієї асоціації. Н. Борден винайшов цей узагальнюючий термін на підставі праць Джеймса Каллітона, який зміст практичної роботи маркетолога звів до поєднання певних складових елементів (інструментів) (Abramova et al., 2016).

Класичними набором маркетингових інструментів вважається, запропонований відомим маркетологом Джеромом МакКарті в 1960 році маркетинг-мікс “4Р”: Product - продукт; Price - ціна; Place - місце, розподіл; Promotion - просування (рис. 1).

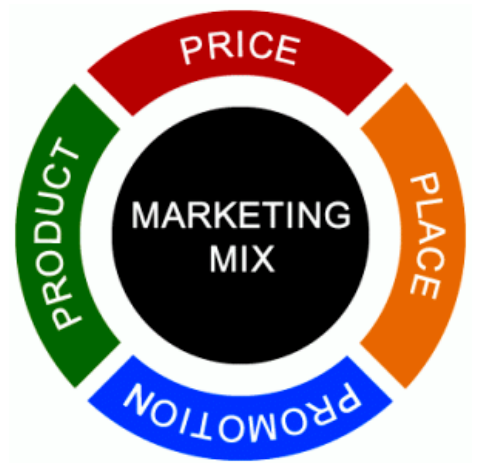

Рис. 1. Класичний набір комплексу маркетингу “4Р”

3 плином часу вихідна ідея маркетингу - орієнтація на потреби споживача - пристосовувалася до особливостей конкретних галузей і країн. 3 60-х років маркетингові інструменти переглядалися, обумовлювалися, доповнювалися та уточнювалися. Типізація цих інструментів призвела до висновку про те, що всі нові інструменти маркетингу або $є$ модифікацією класичних “4Р”, або є характеристиками середовища застосування цих інструментів (Oberemok, 2015).

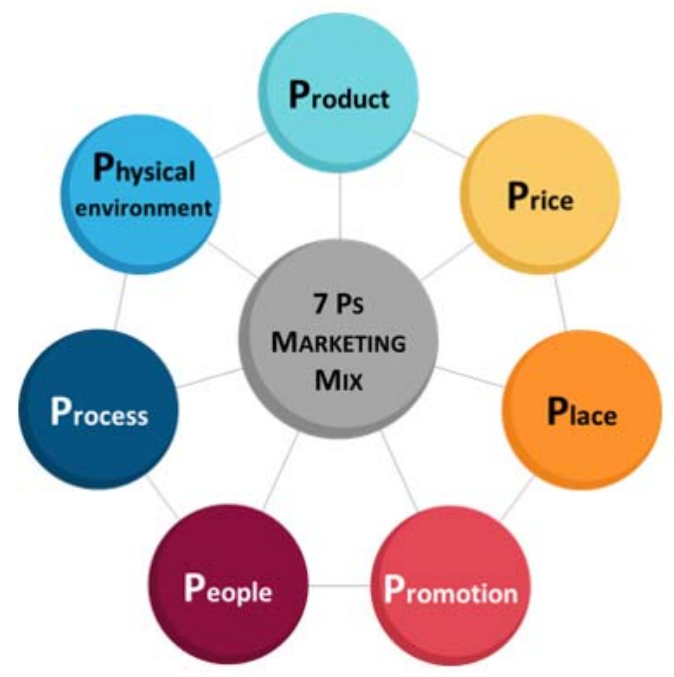

Рис. 2. Маркетинг-мікс “7P”
У 1981 р Б. Бумс і Дж. Бітнер запропонували для сфери послуг збільшити кількість базових елементів комплексу маркетингу до семи. В результаті комплекс маркетингу став включати сім базових елементів “7P": Product - продукт, Price - ціна, Promotion - просування, Place - місце продажу, People - персонал, Physical evidence - здатність надати послугу, а також середовище, у якому послуга надається, Process спосіб надання послуг (рис. 2).

Однак, у сучасному кіберінформаційному та гіперконкурентному бізнес-середовищі для збереження конкурентоспроможності підприємства необхідно не тільки збалансовувати елементи комплексу “4Р” та “7P”, а й безперервно досліджувати та аналізувати споживачів, проводити моніторинг зміни тенденцій 3 метою виявлення першочергових потреб та формувати стратегії їх безумовного задоволення.

Розвиток концепції маркетингу - від ери товарного виробництва до ери людських стосунків - свідчить про те, що в сучасних умовах швидких змін, крім ретельного дослідження ринку, стратегічного та оперативного маркетингового планування, стимулювання збуту, у будь-якій компанії з'являється та виходить на перше місце функція взаємодії зі споживачем у межах всього маркетингового комплексу. Це передбачає спрямованість маркетингової діяльності компанії на встановлення довгострокових, конструктивних, привілейованих стосунків 3 потенційними клієнтами та доповнення класичного комплексу “4Р” інструментами, які враховують індивідуальні особливості споживача (Fomishyna \& Fedorova, 2015).

Цифрова трансформація та інновації $є$ першочерговим та дієвим інструментом вирішення стратегічних завдань для бізнесів усіх рівнів. До незвичайних маркетингових інструментів, можна віднести: Ambient media, Crazy PR, Storytelling, Inbound marketing, Tryvertising, Sensitive marketing, Identity marketing, Shockvertising (рис. 3) (Mozghova, 2013).

1. Ambient media. Нестандартна реклама, яка проникає в оточення цільової аудиторії. Простіше кажучи, вона вбудовується в повсякденне життя, або органічно вписується в оформлення веб-сторінки, а іiі зміст відповідає наповненню сторінки і транслює повідомлення бренду.

Ambient Media - дослівно перекладається, як зовнішні (навколишні) засоби масової інформації. Термін уперше був використаний у другій половині 90-х років у Великобританіі. Сьогодні він має мало загального із традиційними засобами масової інформації. Ambient Media найпростіше охарактеризувати як нестандартну рекламу, у якій основний акцент зроблений на розміщенні. Вона покликана дивувати людей, проникати в їхнє повсякденне життя, - туди, куди традиційним media просто немає ходу. Така реклама розміщується на стінах та на дахах будинків, на потягах і в транспорті, в торгових центрах і кінотеатрах, на майданчиках, у сквері та на сходах, загалом там, де є велика кількість людей (Ruban, 2018). 


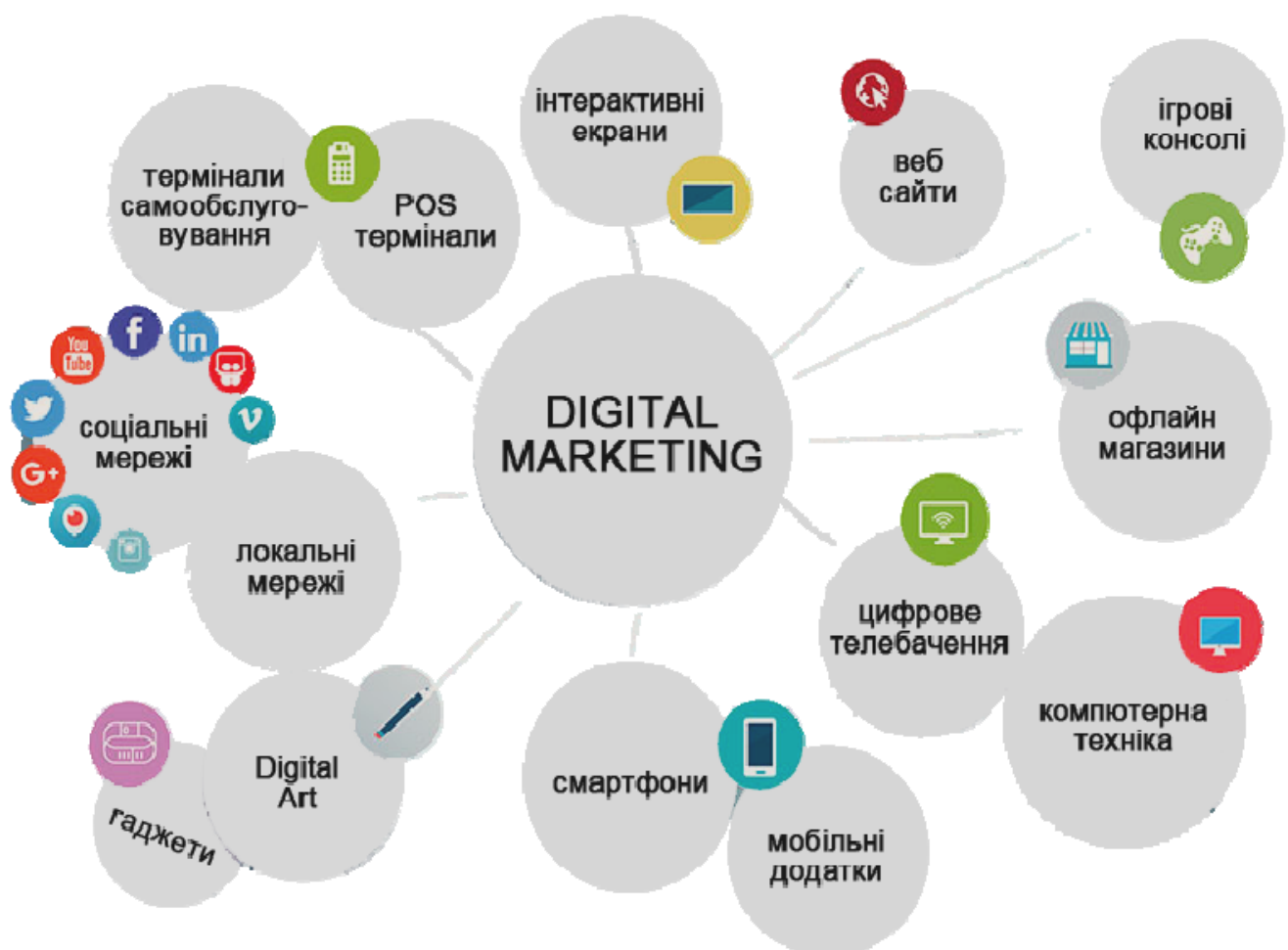

Рис. 3. Модель Digital-маркетингу

Ambient Media переживає досить велику популярність, до якої багато маркетологів ставляться 3 побоюванням. Основна суть Ambient Media полягає в тому, що дана реклама проникає в ті місця, де ії зовсім не чекають побачити - це іiі основна перевага. Адже, люди в сучасному світі навчилися ігнорувати більшу частину класичної реклами. Ambient Media змушує звернути на себе увагу. Ambient Media виділяється на тлі іншої реклами тим, що вона:

- проникає в атмосферу цільової аудиторії (реклама на підлозі, на ручці візка в супермаркеті, на ручці в автобусі);

- відрізняється нестандартністю, високим ступенем креативності й новизною, за рахунок чого залучає до себе увагу великої кількості людей;

- добре піддається плануванню.

B Ambient Media робиться ставка не на охоплення великої аудиторії, а на якісні контакти з потенційними споживачами. У своїй оригінальності в Ambient Media $€$ й недолік. Така реклама може швидко проїсться. I тоді на неї вже не будуть звертати увагу. А тому тут потрібна дійсно серйозно продумана концепція, що буде співвідноситися $з$ рекламованим товаром.

2. Crazy PR. Крейзі піар - від англійського слова “crazy" - несамовитий, хвилюючий та "PR" від "public relations" - зв'язки 3 громадськістю. В основі Crazy PR лежать такі компоненти: креатив, що відповідає за фактор божевільності; підтримка з боку 3МI; орієнтація на цільову аудиторію продукту. Даний спосіб PR відрізняється яскравою творчістю, оскільки його завдання - викликати здивування, зацікавити, спровокувати певною мірою заздрість цільової аудиторії. Тут власне, назва говорить сама за себе. Легка (а іноді i дуже важка) божевільність тільки на користь. Беріть будь-яку екстравагантну ідею і вперед, втілювати в життя. Головне, не переходити межі розумного (i пристойності теж) і простежити за тим, щоб Crazy PR органічно вписувався в позиціонування продукту, послуги або самого бренду.

На думку експертів, традиційні методи реклами, маркетингу i PR відходять на другий план. Споживача сьогодні треба дивувати. Саме ця обставина робить технологію Crazy PR достатньо ефективною.

Переваги Crazy PR: відносно низька ціна; зниження ефективності звичайної реклами; зайнятість і перевантаження суспільства, у результаті чого все важче привернути увагу до продукту. Водночас, головна мета Crazy PR та маркетингу взагалі полягає в тому, щоб створити галас довкола продукту, а потім, перевершити всі очікування споживача.

3. Storytelling. Задовго до появи першого бізнесу шістьма найсильнішими словами на всіх мовах були: “Дозвольте мені розповісти вам одну історію”. Сторітеллінг, або розповідь історій, - інструмент, який надихає, мотивує i, природно, - продає.

Сторітеллінг (Storytelling, "story" - історія; “telling” - розповідати), - це спосіб передачі інформації через розповідання історій. Людство займалося цим весь час: казки, міфи, легенди, плітки, дружні та сімейні історії.

Сторітеллінг був винайдений і успішно випробуваний на особистому досвіді Девідом Армстронгом, головою міжнародної компанії Armstrong International. Розробляючи свій метод, Девід Армстронг врахував відомий психологічний фактор: історії більш виразні, захоплюючі, цікаві та легше асоціюються з особистим досвідом, ніж правила або директиви. Вони краще запам'ятовуються, їм надають бі- 
льшого значення, вони викликають більшу довіру та їх вплив на поведінку людей значно сильніший.

4. Inbound marketing. Вхідний-маркетинг це просування сайту підприємства або продукту в пошукових системах за допомогою блогу i emailмаркетингу за рахунок еmail-розсилок, цікавого, корисного та ефективного для цільової аудиторії контенту. Звісно, без вивчення потреб цієї аудиторії, не обійтись. Користувач за допомогою пошукових систем шукає рішення своєї проблеми i, зацікавившись матеріалами на цю тему, (опублікованими раніше в блозі підприємства) виходить на продавця.

Саме звідси і взялася назва "inbound" - вхідний маркетинг (іноді його називають залучаючим маркетингом).

До inbound-маркетингу (тобто до функцій, які не направлені безпосередньо на споживача) відносять маркетингові дослідження (ринків, споживачів, конкурентів), аналіз конкурентноспроможності, цінову політику, політику позиціювання товарів та підприємства, політику управління брендом та неймінг (визначення назви товару).

Inbound-маркетинг добре працює:

- для виробників 3 довгим циклом продажу коли споживачам потрібно чимало часу, щоб зрозуміти суть і вигоди продукту;

- $\quad$ для підприємств, які виводять на ринок новий продукт, хочуть сформувати на нього попит, зарекомендувати себе;

- $\quad$ для підприємств на висококонкурентних ринках, де вартість оголошень контекстної реклами дуже висока. В цьому випадку inbound-маркетинг дає можливість отримати цільовий трафік з пошукових систем 3 меншими витратами.

Створення якісного контенту за всіма правилами inbound-маркетингу - процес довгий, трудомісткий i клопіткий, але результат того вартий.

5. Tryvertising. Трайвертайзинг (“try” - пробувати) - це новий тренд у рекламі й просуванні товарів, що виробники товарів поряд з ритейлерами можуть використовувати на своє благо й на благо покупця. Перш ніж купити щось, потенційний споживач може познайомитися 3 товаром ближче, наприклад, - спробувати вичавити сік 3 органічних фруктів та овочів, взяти автомобіль на тест-драйв, нанести крапельку парфумів на шкіру і відчути, як розкриється аромат, тощо. Споживачі більше не хочуть купувати «кота в мішку». До того ж, такий маркетинговий інструмент значно підвищує лояльність відношення до споживача, адже якщо людині не потрібен товар, він його не купить і не витратить гроші даремно, а довіра до виробника залишиться у будь-якому випадку.

6. Sensitive marketing. Сенситивність - характерна особливість людини, яка проявляється в підвищеній чутливості до подій, що відбуваються з нею, тобто емоційна чутливість.

Якщо навчитися впливати на всі п'ять органів почуттів споживача - можна отримати потрібний результат. Насправді, з цим інструментом людина зустрічається всюди практично щодня. Ненав'язлива музика в кав'ярнях та магазинах (швидка або повільна
- в залежності від того, як власники хочуть керувати поведінкою відвідувачів), запах свіжої випічки в супермаркеті, що збільшує продажі майже на третину, кольорова гама упаковки та навіть дизайн логотипу все це приклади сенситивного маркетингу.

В ідеалі, маркетинг повинен впливати на шість органів почуттів людини. Шосте - це почуття гумору, адже доведено, коли людина сміється, вона легше розлучається з грошима.

7. Identity marketing. Трапляється, що бренди зі схожою цільовою аудиторією вибудовують маркетинг так, що самі стають схожими один на одного. Тут на допомогу приходить саме identity marketing - маркетинг, заснований на особливостях бренду. Суть його полягає в наступному: потрібно показувати споживачам свою унікальність та ексклюзивність своєї породукції.

8. Shockvertising. Термін походить від двох слів “shock" (шок) i “advertising” (реклама). Все нетипове, непристойне, найбільш шокуюче, найстрахітливіше, що викликає подив і обурення - це і є приклад реклами, яка шокує.

Інструмент виключно для сміливих підприємців. Користуватися ним потрібно дуже обережно, прораховувати можливу реакцію аудиторії та бути готовим до того, що неправильно скориставшись ним - частина людей може відмовитися від продуктів або послуг компанії.

Нерідко великі витрати на маркетингову діяльність не забезпечують очікуваних результатів. Це може бути наслідком неефективного аналізу комплексу маркетингу. Неврахування взаємозв'язків між його елементами та неправильно підібраний комплекс інструментів призводять до нераціонального використання коштів.

\section{Висновки}

Маркетинг - це не просто модне слово чи тренд. Якісна маркетингова стратегія, правильний підбір маркетингових інструментів, дослідження рекламної активності, а також безпосередня орієнтація на потреби споживача, - забезпечують бізнесу необхідний потік клієнтів.

Цифровий маркетинг по праву можна назвати науковою концепцією, яка вивчає процеси, що впливають на реакцію споживачів під дією цифрових медіа та сприяє кращому використанню всіх можливостей для вимірювання ефективності та оптимізації маркетингової діяльності.

Перехід на цифровий формат впливає на всі аспекти маркетингу, включаючи управління іміджем. Час, коли маркетологи могли контролювати імідж компанії, минув. I, як традиційні медіа поступаються дорогою новим медіа, так і компанії повинні перейти від керованого PR до цифрового впливу. Фахівці з маркетингу, які бажають йти в ногу з часом і потребами ринку, повинні забути про старі методи вимірювань, аналізу та почати використовувати передові технології, що працюють у режимі реального часу. 


\section{References}

Abramova, I.M., Bohoiavlenskyi, O.V., Doroshenko, H.O., Doroshenko, O.H., Kravchenko, Ye.O., Lysenko, V.V., Oksenenko, S.P., Penska, I.O., Piddubna, L.V., Tertychnyi, O.O., Tiurina, D.M., \& Yarmak, O.V. (2016). Marketynh: navchalnyi posibnyk. Kharkiv, TOV "Tim Pablish Hrup" (in Ukrainian).

Oberemok, S. (2015). Instrumenty ta tekhnolohii marketynhu: evoliutsiia ta rozvytok na vyperedzhennia. Traektoryia nauky, 1(2-3), 9-20. http://nbuv.gov.ua/UJRN/trna_2015_1_2-3_4 (in Ukrainian).

Fomishyna, V.M., \& Fedorova, N.Ie. (2015). Transformatsiia skladovykh klasychnoho "kompleksu marketynhu pidpryiemstva" u suchasnyi "kompleks marketynhu spozhyvacha". Naukovyi visnyk NLTU Ukrainy, 25(2), 288-293. https://cyberleninka.ru/article/n/transformatsiyaskladovih-klasichnogo-kompleksu-marketingupidpriemstva-u-suchasniy-kompleks-marketinguspozhivacha (in Ukrainian).

Mozghova, V.H. (2013). Instrumenty Internet-marketynhu ta yikh perevahy dlia suchasnykh ukrainskykh pidpryiemstv. Efektyvna ekonomika, 10, 79-86. http://www.economy.nayka.com.ua/?op=1\&z=2429 (in Ukrainian).

Ruban, V.V. (2018). Suchasni instrumenty tsyfrovoho marketynhu. Naukovyi visnyk KhDU, 30(1), 143$146 . \quad$ http://e-visnyk.zdia.zp.ua/journals/2-082017_2/5.pdf (in Ukrainian). 